\title{
Distinct Adsorbed States of DNA and RNA Bases Investigated by Flocculation-Assisted Surface Enhanced Raman Scattering*
}

\author{
Tomomi Mukaiyama, Toru Yajima, and Masayuki Futamata ${ }^{\dagger}$ \\ Graduate School of Science and Engineering, Saitama University, \\ 255 Shimo-Okubo, Sakura-ku, Saitama, 338-8570 Japan
}

(Received 27 December 2014; Accepted 26 March 2015; Published 16 May 2015)

\begin{abstract}
We have succeeded in forming flocculates of gold nanoparticles (AuNPs) using DNA and RNA bases to obtain their surface enhanced Raman spectra. Adenine, guanine and cytosine molecules which possess a primary amino group $\left(-\mathrm{NH}_{2}\right)$ formed flocculates at much lower concentration than uracil and thymine without an $-\mathrm{NH}_{2}$ group, suggesting a crucial role of an $-\mathrm{NH}_{2}$ group for adsorption of these base molecules on neighboring AuNPs. Detailed adsorption structure of base molecules was investigated using their SERS spectra at various $\mathrm{pH}$ in solutions and those for deuterated bases, comparing with those for bulk state and also by DFT calculations.

[DOI: $10.1380 /$ ejssnt.2015.223]
\end{abstract}

Keywords: Flocculation; Localized surface plasmon; Gold nanoparticles; Surface enhanced Raman scattering; A gap mode

\section{INTRODUCTION}

Attainment of enormous enhancement with high reproducibility is critical for the utilization of SERS in quantitative analysis. Single molecule detection by Raman scattering has been investigated using a coupled localized surface plasmon (LSP) of adjacent metal nanostructures, by controlling the nanogap size and the adsorption of target molecules $[1,2]$. For this purpose, we have studied flocculates of silver and gold nanoparticles (AgNPs, and AuNPs), which are a few closely adjacent nanoparticles, providing various molecules with enormous SERS intensity in solutions [3-7]. Theoretical calculations suggest that one of AgNPs or AuNPs in flocculates can be replaced with metal substrates [8], such as $\mathrm{Pd}, \mathrm{Fe}, \mathrm{Ni}$, $\mathrm{Zn}, \mathrm{Al}$ and $\mathrm{Pt}[9-12]$ having large damping factors of surface plasmon, while providing enormous enhancement factors in SERS equivalent to those obtained in flocculates of AgNPs and AuNPs. Furthermore, MNPs can be attached to the tip of cantilevers or sharpened optical fiber probes for near-field Raman spectroscopy. Such fabrication is expected to provide us with Raman images in single molecule sensitivity and a spatial resolution of a few nanometers $[13,14]$.

However, we have experimental limitations in the utilization of the gap mode of metal nanostructures. For instance, addition of target molecules or salts to suspension of MNPs for fabrication of flocculates often causes coagulation or precipitation of MNPs. Coagulation of MNPs may give rather large SERS enhancement but fails in getting good reproducibility. In general, MNPs are isolated by electrostatic repulsion between counter ions in an electrical double layer on MNPs, as rationalized by the DLVO (Derjaguin-Landau-Verway-Oberveek) theory [15]. Indeed, the surface of AgNPs or AuNPs prepared by chemical reduction using trisodium citrate is covered with residual citrate anions through sodium cations in close proximity to the MNP surfaces. Substitution of such surface residuals with suitable chemicals is neces-

\footnotetext{
* This paper was presented at the 7th International Symposium on Surface Science, Shimane Prefectural Convention Center $(\mathrm{Ku}-$ nibiki Messe), Matsue, Japan, November 2-6, 2014.

$\dagger$ Corresponding author: futamata@chem.saitama-u.ac.jp
}

sary for us to suppress steric hindrance by citrate anions for efficient adsorption of cationic xanthene and triphenyl methane dyes $[3,4,6,8]$. A larger amount of surface residuals such as a layer of citrates and oxides on AgNPs does not allow the chemisorption of neutral molecules. Indeed only cationic xanthene and triphenylmethane dyes are adsorbed on AgNPs to form flocculates [3, 4]. Formation of self-assembled monolayers (SAM) of thiol molecules with functional groups such as carboxylic and amino groups is a promising way to form flocculates of AgNPs and to attain enormous SERS enhancement by trapping various molecules between neighboring AgNPs coated with SAMfilm $[5,16]$.

In contrast to AgNPs, neutralized R123 molecules adsorb on AuNPs via a coordination bond of $\mathrm{Au}-\mathrm{N}$ in a tilted orientation in sufficiently low coverage of citrates, whereas cationic rhodamine 123 (R123) molecules adsorb on AuNPs through electrostatic interaction in parallel to the interparticle axis [6, 7]. Similarly, AuNPs are incubated into a living cell to monitor $\mathrm{pH}$ distribution [1], and used to detect hybridization of DNA [17]. Although single molecule detection is required in DNA sequencing [18], Raman spectroscopy has not been used in such challenging purpose. Indeed, DNA bases or other biomolecules are not directly characterized in such applications, but monitored by the faint differences in conductivity at a nanogap for individual DNA bases [18]. This is partly due to intrinsic difficulty in detecting and distinguishing Raman spectra for individual DNA bases passing through a nanogap. In principle, the same base molecules in different sequences can provide distinct Raman spectra in a flocculation of AuNPs, due to different enhancement for different distance from $\mathrm{Au}$ surfaces, and also due to distinct interaction with neighboring molecules, albeit the differences are inherently small [19]. For precise sequencing in DNA molecules by Raman spectroscopy, one should start with characterization of individual DNA and RNA bases, adenine $(\mathrm{A})$, guanine $(\mathrm{G})$, cytosine $(\mathrm{C})$, thymine (T) and uracil (U) molecules, adsorbed on AuNP surfaces, which has not been sufficiently elucidated as seen in recent reports [20-22]. In the next step, nucleotide and DNA molecules will be studied to detect inherently faint differences in Raman spectra of DNA bases under quite similar circumstances. Here we focused ourselves on distinct adsorption structure of various DNA and RNA bases on $\mathrm{Au}$ 
surfaces using flocculation-SERS method at different $\mathrm{pH}$ conditions. Interestingly, we found that base molecules with primary amino groups $\left(-\mathrm{NH}_{2}\right)$ showed much more feasible adsorption than those without $-\mathrm{NH}_{2}$, whereas those bases without $-\mathrm{NH}_{2}$ showed significantly higher critical concentration for flocculation of AuNPs. These adsorption features are explained by distinct adsorbed structure of base molecules on Au surfaces with the help of isotope shift in Raman band and also DFT calculations.

\section{EXPERIMENTAL DETAILS}

Gold nanoparticles were prepared by a citrate reduction method [6, 7]. Shortly, AuNPs were prepared using the citrate reduction method reported by Frens [23]. Briefly, a trisodium citrate solution $(20 \mathrm{mg}$ in $10 \mathrm{~mL}$ solution, i.e. $1 \%$ aq. solution) was added to a $\mathrm{HAuCl}_{4} \cdot 4 \mathrm{H}_{2} \mathrm{O}(20 \mathrm{mg}$ in $200 \mathrm{~mL}$ ) aqueous solution under reflux, and then the reacting solution was kept at $100^{\circ} \mathrm{C}$ for 5 min. The AuNPs thus prepared (called 'as-prepared AuNPs') were mostly spherical with a diameter of ca. $20 \mathrm{~nm}$ according to SEM measurements (data not shown), although AuNPs larger than $100 \mathrm{~nm}$ were occasionally observed owing to the limited incubation time. As-prepared AuNP suspension showed $\mathrm{pH} \sim 4.3$, which is mostly governed by initial concentration of strong acid $\mathrm{HAuCl}_{4}(\sim 0.3 \mathrm{mM})$. Extinction spectra were measured for the AuNP dispersed solutions after cooling to room temperature $\left(20-23^{\circ} \mathrm{C}\right)$.

Surface of AuNPs are covered by citrate anions, which stabilize AuNPs via electrostatic repulsion between cationic layers, consisting of hydrated counter ions, surroundings of each AuNP. As explained by DLVO theory, the stability of MNPs is governed by the concentration of counter ions in solution for AuNPs with definite amount of citrates anions on their surfaces. Namely, at the higher concentration of cations in solutions, the thinner layer of the counter ions surroundings of each AuNP. Accordingly, van der Waals attractive force becomes crucial to form flocculates. Consequently, one should adjust the concentration of salt in solutions to detect extremely low concentration of target molecules. Also, note that flocculation is a quite slow kinetic process, yielding gradual growth of flocculates with time. Although surface residuals with negative charges like citrate anions stabilize AuNPs suspensions by the electrostatic repulsion between cationic ion layer surroundings of AuNPs, too much amount of citrates on AuNPs result in deficient adsorption sites for neutral molecules. Surface coverage of citrates on AuNPs is determined by the initial amount which would be used for reducing $\mathrm{HAuCl}_{4}$, and also by reaction conditions such as temperature and reaction time. One must compromise or find appropriate surface coverage of citrate between stability of AuNPs suspension and adsorbed quantity of target molecules. In this study, we used as-prepared AuNP suspensions, with $\mathrm{pH} \sim 4.3$, mixed with different DNA and RNA base solutions at $2 \times 10^{-3} \sim 1 \times 10^{-7} \mathrm{M}$, while adding acid $\left(\mathrm{H}_{2} \mathrm{SO}_{4}\right)$, and base $(\mathrm{NaOH})$ to tune $\mathrm{pH}$ in solutions. Here, the same batch of AuNP suspensions were used, which assure essentially the same amount of surface residuals and concentration of AuNPs. We also investigated isotope shift of Raman bands of base molecules, by substituting hydrogen to deuterium at amino groups, $>\mathrm{N}-\mathrm{H}$ and $-\mathrm{NH}_{2}$, in base molecules, which were achieved simply by immersing base molecules in deuterated water $\left(\mathrm{D}_{2} \mathrm{O}\right)$ for more than $1 \mathrm{hr}$, and also by dispersing AuNPs suspension for more than $1 \mathrm{hr}$ after centrifugation to remove ordinary water $\left(\mathrm{H}_{2} \mathrm{O}\right)$. More than $90 \%$ of hydrogen atoms at amino groups of DNA bases were replaced with deuterium with such procedure, which is sufficiently high to detect isotope shift of Raman bands.

Modified micro Raman spectrometer (Renishow, Research series) with CCD camera was employed to observe Raman spectra of samples in flocculates of AuNPs in solutions or in bulk powder state. Extinction spectra of AuNPs were measured to characterize flocculation of AuNPs, which were formed by mixing AuNP suspensions with solutions of base molecules at different $\mathrm{pH}$ followed by incubation for $1 \mathrm{hr}$, with JASCO U-530 uv-vis spectrometer. DFT calculations were performed for neutral and protonated DNA and RNA base molecules at B3LYP/6-311+G(d, p) for C, N, H and O and B3LYP/SDD for $\mathrm{Au}$ atoms. Continuum solvation model was adopted to reproduce SERS spectra of base molecules in flocculation of AuNPs in aqueous solutions. Each AuNP was modeled to be a single gold atom to evaluate the effect of adsorption of base molecules to AuNPs. Differential Raman scattering cross section was estimated for vibrational modes in DFT calculations [24, 25], which was compared with those experimentally observed Raman spectra. Potential energy distribution of each Raman band was estimated with using a software VEDA 4.0 [28].

\section{RESULTS AND DISCUSSION}

\section{A. Adsorption of DNA and RNA base molecules}

Adsorption of all the DNA and RNA bases (Figs. 1a-1e) generated flocculation of AuNPs as evidenced by appearance of a coupled LSP peak centered around 700-810 nm (Figs. 2a-2e) in addition to LSP peak at $522 \mathrm{~nm}$ from isolated AuNPs. Critical concentrations for the flocculation (ccf), which is the lowest concentration for AuNPs to flocculate, depended on molecular structure of base molecules. Indeed, adenine $(\mathrm{A})$, guanine $(\mathrm{G})$, and cytosine (C) flocculated at $3 \times 10^{-7}, 6 \times 10^{-7}$, and $5 \times 10^{-6} \mathrm{M}$, whereas uracil $(\mathrm{U})$ and thymine $(\mathrm{T})$ flocculated at much higher concentration of $1.5 \times 10^{-3}$ and $5 \times 10^{-4} \mathrm{M}$, respectively. As mentioned in experimental section, ccf values are inherently affected by the amount of negative charge on each AuNP and concentration of AuNPs, we used the same batch of AuNPs suspension for these experiments. Hence, distinct ccf values observed for different base molecules are intrinsic, which result from different molecular structures and chemical properties. Thus, bases of $\mathrm{A}, \mathrm{G}$ and $\mathrm{C}$ with a primary amino group $\left(-\mathrm{NH}_{2}\right)$ showed much lower critical concentrations than those of $\mathrm{T}$ and $\mathrm{U}$ without an $-\mathrm{NH}_{2}$ group. Higher ccf values for $\mathrm{A}, \mathrm{G}$ and $\mathrm{C}$ suggest much stronger interaction of these bases with Au surfaces compared with $\mathrm{T}$ and $\mathrm{U}$, which is consistent with former reports on thermal stability of DNA bases adsorbed on gold [27]. Preferential adsorption of A, G and $\mathrm{C}$ is presumably due to coordination of a lone pair electrons located in purine and pyrimidine rings. Also it is possibly due to distinct electronic state of these bases, 
(a) Adenine

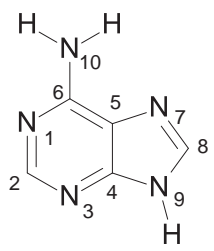

(d) Thymine

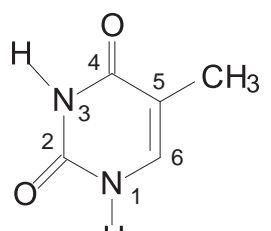

$\mathrm{H}$ (c) Cytosine

$$
\text { (N) }
$$

(e) Uracil

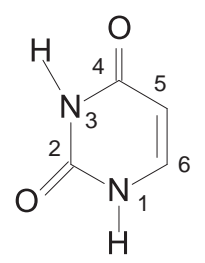

FIG. 1. Molecular structure of DNA and RNA bases: (a) adenine A, (b) guanine $\mathrm{G}$, (c) cytosine $\mathrm{C}$, (d) thymine $\mathrm{T}$, and (e) uracil U. At $\mathrm{pH}<\mathrm{pK}_{\mathrm{a} 1}$ (3.3-4.6), imino groups at $\mathrm{N}_{1}$ (A), $\mathrm{N}_{7}(\mathrm{G})$, and $\mathrm{N}_{3}(\mathrm{C})$ are protonated. Similarly, imino groups at $\mathrm{N}_{9}(\mathrm{~A}), \mathrm{N}_{1}(\mathrm{G}), \mathrm{N}_{1}(\mathrm{C}), \mathrm{N}_{3}(\mathrm{~T}, \mathrm{U})$ are deprotonated at $\mathrm{pH}>\mathrm{pK}_{\mathrm{a} 2}$ (ca. 9-10).
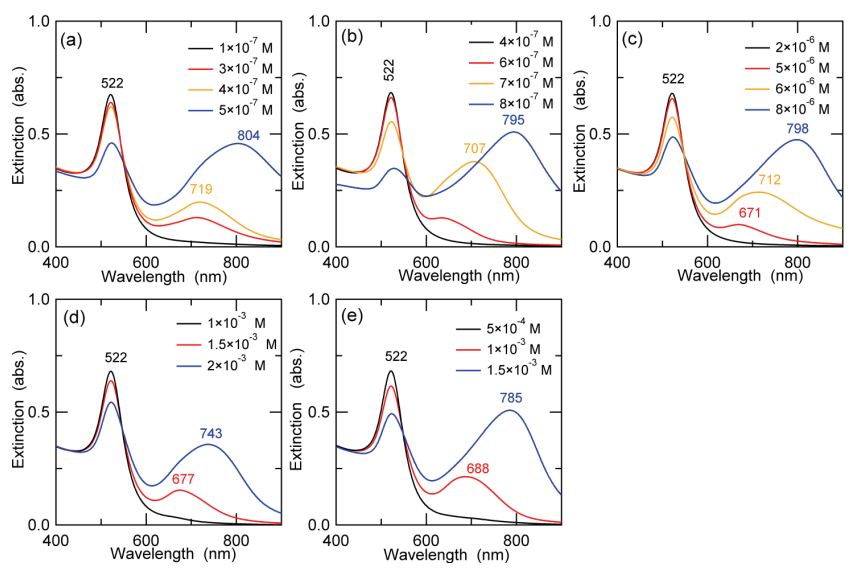

FIG. 2. Extinction spectra of AuNP (as prepared, $\mathrm{pH}=4.3$ ) suspensions mixed with solutions containing DNA bases: (a) A, (b) G, (c) C, (d) T, and (e) U.

of which adsorption on AuNPs is stabilized by an $-\mathrm{NH}_{2}$ group. However, the situation for distinct flocculation of AuNPs by different base molecules is much more complicated than anticipated.

To clarify the origin of distinct ccf values, we investigated the effect of protonation on ccf values of DNA bases. Occasionally, pH of our sample solutions containing AuNPs and DNA bases is around 4.3 determined by initial concentration of $\mathrm{HAuCl}_{4}(\sim 0.3 \mathrm{mM})$, which is close to $\mathrm{pK}_{a}$ of the imino groups ( $>\mathrm{N}$ :) A (4.2), G (3.3), and $\mathrm{C}$ (4.6) [29]. Protonation at an imino group ( $>\mathrm{N}$ site), next to the carbon combined with an $-\mathrm{NH}_{2}$ group in $\mathrm{A}$, $\mathrm{G}$ and $\mathrm{C}$ molecules occurs at such low $\mathrm{pH}$ probably due to electron donating effect of an $-\mathrm{NH}_{2}$ group. Indeed, $\mathrm{T}$ and $\mathrm{U}$ molecules without an $-\mathrm{NH}_{2}$ group have no such $\mathrm{pK}_{a}$, while they have $\mathrm{pK}_{a}$ of 9.4-9.5 for an imino group ( $>\mathrm{N}$ :
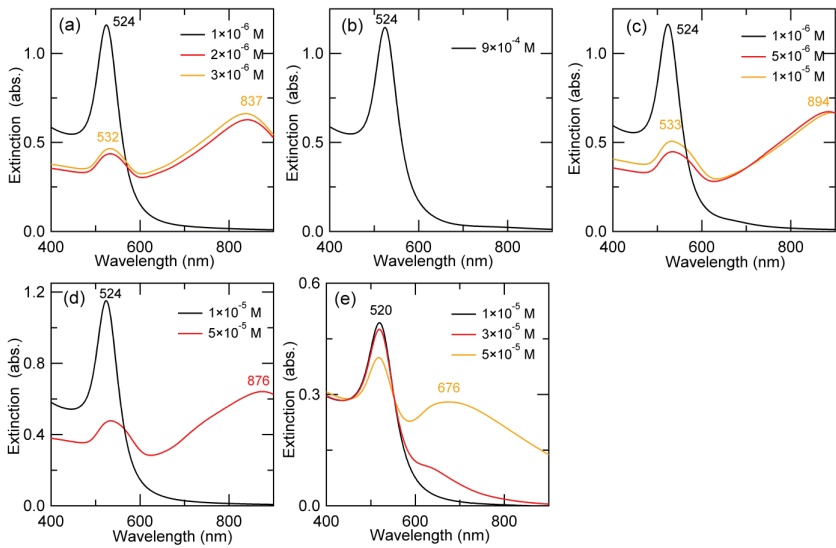

FIG. 3. Extinction spectra of AuNP suspensions mixed with solutions containing DNA bases at $\mathrm{pH}=6.8$ : (a) A, (b) A (at $\mathrm{pH}=12.2$ ), (c) C, (d) T, and (e) U. Only Fig. 3b was observed at $\mathrm{pH}=12.2$, revealing AuNPs gradually start flocculation at $9 \times 10^{-4} \mathrm{M}$ of $\mathrm{A}$.

at $\mathrm{N}_{3}$ site). Accordingly, $\mathrm{A}, \mathrm{G}$ and $\mathrm{C}$ molecules with an $-\mathrm{NH}_{2}$ group are mostly protonated to be cationic species $\left(>\mathrm{N}-\mathrm{H}^{+}\right)$in AuNP suspensions of $\mathrm{pH} \sim 4.3$. Here, $\mathrm{A}, \mathrm{G}$, and $\mathrm{C}$ molecules adsorb on AuNPs at $\mathrm{pH}<\mathrm{pK}_{a}$ with electrostatic interaction between positive charge in DNA bases and negatively charged AuNPs (see also Experimental Details), in addition to chemisorption via a lone pair electrons at nitrogen atoms in base molecules. Electrostatic interaction between cationic molecules and anionic charges on AuNPs are much stronger $\left(\sim 1000 \mathrm{kJmol}^{-1}\right)$ than thermal energy $\left(2.5 \mathrm{kJmol}^{-1}\right.$ at $\left.300 \mathrm{~K}\right)$, and comparable with those of coordination bond via lone pair electrons [15]. To derive the contribution of chemisorption via lone pair electrons to flocculation of AuNP, $\mathrm{pH}$ in solutions containing AuNPs and these base molecules was tuned between 1.8-12.2. For instance, the critical concentration for flocculation of AuNPs (Fig. 3a) was quite similar at $\mathrm{pH}=6.8\left(2 \times 10^{-6} \mathrm{M}\right)$ to those at $\mathrm{pH}=1.8$ $\left(3 \times 10^{-7} \mathrm{M}\right)$ and $4.3\left(3 \times 10^{-7} \mathrm{M}\right)$ for adenine, indicating the possibility that chemisorption via lone pair electrons at amino groups in base molecules plays a crucial role in flocculation of AuNPs irrespective of their protonated or deprotonated state, rather than electrostatic interaction between protonated adenine and negatively charged AuNPs. This possibility was supported by the observation of a Raman band at $223-238 \mathrm{~cm}^{-1}$ for adenine on AuNPs at acidic and neutral $\mathrm{pH}$ conditions, which is assigned to a $\nu_{\mathrm{Au}-\mathrm{N}}$ stretching mode as described in the next section. In contrast to the observations in acidic and neutral $\mathrm{pH}$ solutions, much higher concentration was necessary for starting flocculation at $\mathrm{pH}=12.2\left(9 \times 10^{-4} \mathrm{M}\right.$, Fig. 3b). This result is clearly due to electrostatic repulsion between deprotonated adenine, of which $\mathrm{pK}_{a 2}$ is 9.8, and negatively charged AuNPs. Essentially the same results were observed for guanine and cytosine as those for adenine that ccf values for these bases are similar at acidic and neutral $\mathrm{pH}$, such as $5 \times 10^{-6} \mathrm{M}(\mathrm{pH}=4.3)$, and $5 \times 10^{-6} \mathrm{M}(\mathrm{pH}=6-7)$ for cytosine (Figs. 2c, 3c).

In contrast, $\mathrm{T}$ and $\mathrm{U}$ molecules showed significantly higher ccf values in acidic $\mathrm{pH}$ conditions compared to neutral $\mathrm{pH}$, such as $5 \times 10^{-5} \mathrm{M}(\mathrm{pH}=6.8)$ and 
$5 \times 10^{-4} \mathrm{M}(\mathrm{pH}=4.3)$ for $\mathrm{T}$, and $3 \times 10^{-5} \mathrm{M}(\mathrm{pH}=6.8)$ and $1.5 \times 10^{-3} \mathrm{M}(\mathrm{pH}=4.3)$ for $\mathrm{U}$ molecules. In the DLVO theory, stability of colloidal particles in solution is determined by a competition of electrostatic repulsion between counter ions of surface charges, and van der Waals attractive interaction between nanoparticles [15]. According to this theory, ccf values should be diminished by increasing ionic strength, which decreases the thickness of double layer formed by counter ions. Nevertheless, addition of sulfuric acid to mixed solution of AuNPs and T (or U) molecules up to $\sim 10 \mathrm{mM}$ increased the ccf of AuNPs. Recalling that $\mathrm{T}$ and $\mathrm{U}$ are neutral molecules at $\mathrm{pH}$ regions between 2.0 and 7.0, the observed $\mathrm{pH}$ dependence of ccf values for $\mathrm{U}$ and $\mathrm{T}$ result from their adsorbed structures. For instance, if $\mathrm{T}$ and $\mathrm{U}$ adsorb on Au surfaces via an $>\mathrm{N}$ $\mathrm{Au}$ coordination bond, deprotonation of an $\mathrm{N}-\mathrm{H}$ bond is prerequisite (Fig. 1), which is likely inhibited in acidic solutions. This assumption was supported by experimental Raman band for a $\nu_{\mathrm{Au}-\mathrm{N}}$ mode, such as at $\sim 220 \mathrm{~cm}^{-1}$ for $\mathrm{U}$ and $\mathrm{T}$, and DFT calculations for these bases adsorbed on AuNPs (Section 3.3, see also [20]). Much lower ccf values observed for $\mathrm{T}$ and $\mathrm{U}$ bases at neutral $\mathrm{pH}$ occasionally reduces differences in ccf values against $A, G$ and $\mathrm{C}$ molecules. Nevertheless, absolute ccf values for A, $\mathrm{G}$ and $\mathrm{C}$ bases increased only by a factor of 6 at neutral $\mathrm{pH}$ (vide infra). This observation is again caused by the molecular structure of $\mathrm{A}, \mathrm{G}$, and $\mathrm{C}$ having $>\mathrm{N}$ and $>\mathrm{N}-\mathrm{H}$ bonds, since deprotonation is unnecessary for A, G and C to adsorb on AuNPs with a coordination bond $>\mathrm{N}-\mathrm{Au}$.

Consequently, flocculation of AuNPs observed for different DNA and RNA bases are primarily caused by the formation of an $\mathrm{Au}-\mathrm{N}$ coordination bond. Adsorption of these base molecules on $\mathrm{Au}$ surfaces are facilitated by an $-\mathrm{NH}_{2}$ group, while those for base molecules without an $-\mathrm{NH}_{2}$ group shows $\mathrm{pH}$ dependent ccf values. In the next section, we describe details on adsorbed structures of distinct bases $\mathrm{A}$ and $\mathrm{U}$ on the basis of their Raman spectra observed in bulk powder, in flocculates of AuNPs, and DFT calculations.

\section{B. Adsorbed state of adenine molecules on AuNPs}

First, we investigated adsorbed state of adenine, representing base molecules with an $-\mathrm{NH}_{2}$ group. Adenine on AuNPs showed quite similar Raman spectra at acidic $(\mathrm{pH}=4.3$, and 1.8) and neutral $\mathrm{pH}$ (6.8) in solutions, which are almost identical to those of bulk powder (Figs. 4a-4c, Table I). In solutions, adenine is protonated $\left(>\mathrm{N}_{1}-\mathrm{H}^{+},>\mathrm{N}_{10}-\mathrm{H}\right)$ at $\mathrm{pH}$ lower than $\mathrm{pK}_{a 1}$ $(=4.2)$, neutral $\left(>\mathrm{N}_{1},>\mathrm{N}_{10}-\mathrm{H}\right)$ at $\mathrm{pH}$ between 4.3 and 9.3 , whereas deprotonated $\left(\left(>\mathrm{N}_{1},>\mathrm{N}_{9}^{-}\right)\right.$at $\mathrm{pH}$ higher than $\mathrm{pK}_{a 2}(=9.3)$. As described above, adenine anions formed flocculates of AuNPs at quite high concentrations. Protonated adenine showed Raman bands at 1648, 1567, 1514, 1460, 1399, 1342, 1312, 1230, 1108, 1013, 958, 730, $616,540,313$ and $238 \mathrm{~cm}^{-1}$, while neutral adenine showed quite similar Raman bands at 1643, 1543, 1510, 1455, 1394, 1372, 1335, 1317, 1268, 1233, 1023, 960, 730, 621, 554,323 , and $223 \mathrm{~cm}^{-1}$. Only faint changes in peak positions and intensity were observed for SERS bands at 1372, 1268 and $1023 \mathrm{~cm}^{-1}$ in neutral $\mathrm{pH}$, compared to those in acidic condition. We observed a $\nu_{\mathrm{Au}-\mathrm{N}}$ mode at

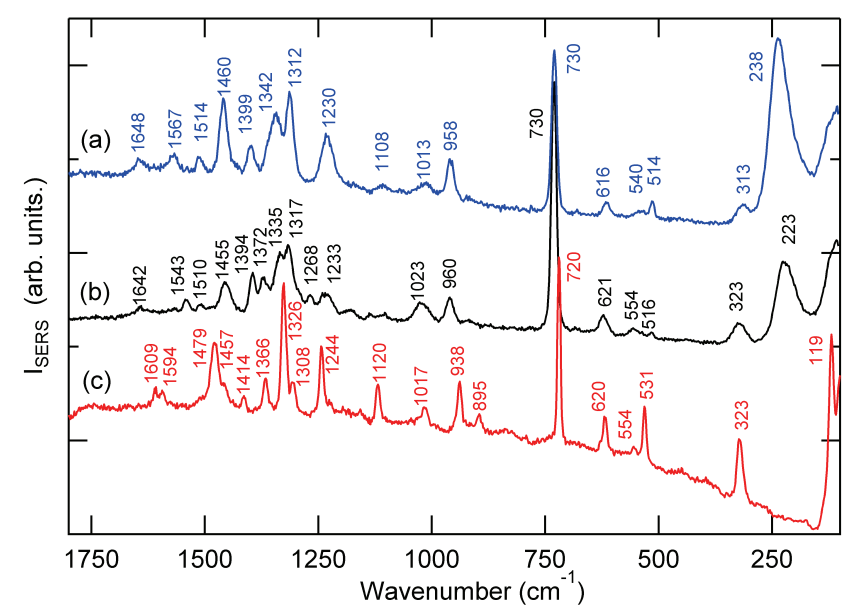

FIG. 4. Raman spectra of adenine adsorbed on AuNPs: (a) at acidic $(\mathrm{pH}=4.3)$, and $(\mathrm{b})$ neutral $\mathrm{pH}(\sim 6.8)$, in addition to those observed at bulk powder (c, neutral adenine molecules). Raman spectra of $\mathrm{A}$ on AuNPs at $\mathrm{pH}=1.8$ were inherently the same as those at $\mathrm{pH}=4.3$.

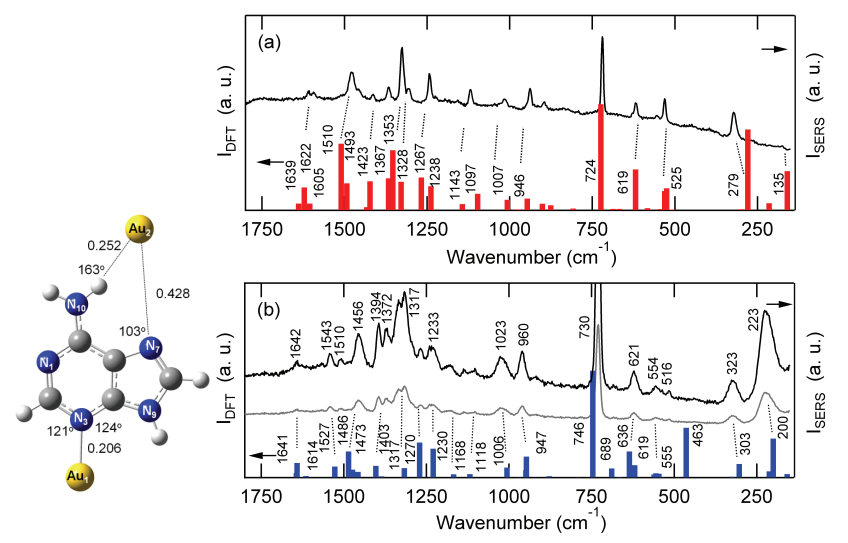

FIG. 5. Calculated Raman spectra of adenine: (a) a freestanding state, and (b) adsorbed state on AuNPs. In the adsorbed state, adenine chemisorbs via $\mathrm{N}_{3}-\mathrm{Au}$, and simultaneously physisorbs via close vicinity of $-\mathrm{N}_{10} \mathrm{H}_{2}$ groups on $\mathrm{Au}$ atoms. Experimentally observed spectra are also shown at upper side of each figure. Plausible optimized structure of A adsorbed on Au using DFT calculation is also shown, which is stabilized by a coordination bond of $\mathrm{N}_{3}-\mathrm{Au}_{1}$, and weak interaction between $-\mathrm{N}_{10} \mathrm{H}_{2}$ and $\mathrm{Au}_{2}$ atoms.

$238 \mathrm{~cm}^{-1}\left(223 \mathrm{~cm}^{-1}\right)$, which proves formation of a $\mathrm{N}-\mathrm{Au}$ coordination bond in acidic and neutral $\mathrm{pH}$ irrespective of protonated or neutral state of adenine. Red-shift of $\mathrm{Au}-\mathrm{N}$ stretching mode from $238(\mathrm{pH}=4.3)$ to $223 \mathrm{~cm}^{-1}$ (6.8), which was detected only for adsorbed state, suggests slightly weaker $\mathrm{Au}-\mathrm{N}$ bond for neutral state compared with protonated state. Quite similar Raman spectra observed in acidic and neutral $\mathrm{pH}$ solutions indicate that adsorbed state of adenine molecules on AuNPs are inherently identical for cationic and neutral state which is governed by coordination of lone pair electrons at an imino group, as supported by their similar critical concentration for flocculation.

We performed DFT calculations for a free-standing ade- 
TABLE I. Experimental and calculated Raman peak wavenumber for free-standing and adsorbed adenine and uracil molecules $\left(\mathrm{cm}^{-1}\right)$.

\begin{tabular}{|c|c|c|c|c|c|c|c|}
\hline & $\begin{array}{l}\text { Bulk } \\
\text { powder } \\
\text { (obsd.) }\end{array}$ & $\begin{array}{l}\text { SERS at } \\
\mathrm{pH}=4.2 \\
\text { (obsd.) }\end{array}$ & $\begin{array}{l}\text { SERS at } \\
\mathrm{pH}=6.8 \\
\text { (obsd.) }\end{array}$ & $\begin{array}{l}\text { SERS for } \\
\text { deuterated } \\
>\mathrm{N}-\mathrm{D} \text { (obsd.) }\end{array}$ & $\begin{array}{l}\text { Free-neutral } \\
\text { state } \\
\text { (calcd.) }\end{array}$ & 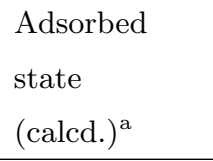 & Assignment $^{+}$ \\
\hline \multirow[t]{22}{*}{ Adenine } & & 1648 & 1642 & & 1639 & 1643,1641 & $\delta_{\mathrm{sci}}\left(-\mathrm{NH}_{2}\right), \nu\left(\mathrm{N}_{10}-\mathrm{C}_{6}\right)$ \\
\hline & 1609,1594 & 1567 & 1543 & 1537,1509 & 1622,1605 & 1614 & $\nu\left(\mathrm{N}_{3}-\mathrm{C}_{4}\right), \nu\left(\mathrm{N}_{1}-\mathrm{C}_{6}\right)$ \\
\hline & & 1514 & 1510 & & 1510 & 1527 & $\nu\left(\mathrm{N}_{7}-\mathrm{C}_{8}\right), \delta\left(\mathrm{C}_{8}-\mathrm{H}\right)$ \\
\hline & 1479,1457 & 1460 & 1455 & 1440 & 1492 & 1486,1473 & $\delta\left(\mathrm{C}_{6}-\mathrm{H}\right), \nu\left(\mathrm{N}_{1}-\mathrm{C}_{6}\right)$ \\
\hline & 1414 & 1399 & 1394 & 1373 & 1423 & 1457 & $\nu\left(\mathrm{C}_{4}-\mathrm{N}_{9}\right), \delta\left(\mathrm{N}_{9}-\mathrm{H}\right)$ \\
\hline & 1366 & 1342 & 1372 & & 1367 & 1403 & $\delta\left(\mathrm{C}_{2}-\mathrm{H}\right), \nu\left(\mathrm{C}_{8}-\mathrm{N}_{9}\right)$ \\
\hline & & & 1335 & 1342 & 1353 & 1386 & $\nu\left(\mathrm{C}_{2}-\mathrm{N}_{1}\right), \nu\left(\mathrm{C}_{5}-\mathrm{N}_{7}\right)$ \\
\hline & 1326,1308 & 1312 & 1317 & 1299 & 1328 & 1317 & $\nu\left(\mathrm{N}_{3}-\mathrm{C}_{2}\right), \nu\left(\mathrm{C}_{2}-\mathrm{N}_{1}\right)$ \\
\hline & & 1268 & 1268 & 1262 & 1267 & 1270 & $\nu\left(\mathrm{N}_{7}-\mathrm{C}_{8}\right), \delta\left(\mathrm{C}_{8}-\mathrm{H}\right)$ \\
\hline & & 1230 & 1233 & & 1238 & 1230 & $\nu\left(\mathrm{C}_{5}-\mathrm{N}_{7}\right), \delta\left(\mathrm{NH}_{2}\right)$ \\
\hline & 1244 & & & 1186 & 1143 & 1168 & $\nu(\mathrm{N}-\mathrm{C}(\mathrm{R} 6), \delta(\mathrm{CNC})$ \\
\hline & 1120 & 1108 & & 1099 & 1097 & 1118 & $\nu\left(\mathrm{C}_{8}-\mathrm{N}_{9}\right), \delta\left(\mathrm{N}_{9}-\mathrm{H}\right)$ \\
\hline & 1017 & 1013 & 1023 & & 1007 & 1006 & $\delta_{\text {rock }}\left(-\mathrm{NH}_{2}\right), \nu\left(\mathrm{N}_{1}-\mathrm{C}_{6}\right)$ \\
\hline & 938 & 958 & 960 & & 946 & 949,947 & $\delta(\mathrm{R} 5)$ \\
\hline & 895 & & & 851 & 901 & & $\delta(\mathrm{R} 6)$ \\
\hline & 720 & 730 & 730 & 725 & 724 & 746 & Ring breathing \\
\hline & & & & 680 & & 689 & $\delta(\mathrm{R} 5), \delta(\mathrm{R} 6)$ \\
\hline & 620 & 616 & 621 & 611 & 618 & 636,619 & $\delta(\mathrm{R} 5), \delta(\mathrm{R} 6)$ \\
\hline & 554,531 & 540 & 554,516 & 541 & 525 & $560,555,546$ & $\delta(\mathrm{R} 5), \delta(\mathrm{R} 6)$ \\
\hline & & & & & & 463 & $\omega_{\mathrm{wag}}\left(-\mathrm{NH}_{2}\right)$ \\
\hline & 323 & 313 & 321 & 299 & 279 & 303 & $\delta(\mathrm{R} 5), \delta(\mathrm{R} 6)$ \\
\hline & & 238 & 223 & & & & $\nu(\mathrm{N}-\mathrm{Au})$ \\
\hline \multirow[t]{17}{*}{ Uracil } & 1712 & & 1642 & & 1749,1698 & 1675 & $\nu\left(\mathrm{C}_{2}=\mathrm{O}\right), \nu\left(\mathrm{C}_{4}=\mathrm{O}\right)$ \\
\hline & 1643 & & 1625 & 1619,1576 & 1667 & 1603 & $\nu\left(\mathrm{C}_{5}-\mathrm{C}_{6}\right), \delta\left(\mathrm{C}_{6}-\mathrm{H}\right)$ \\
\hline & 1502 & & 1500 & 1520 & 1508 & 1574 & $\delta\left(\mathrm{N}_{1}-\mathrm{H}\right), \nu\left(\mathrm{N}_{1}-\mathrm{C}_{6}\right)$ \\
\hline & 1454,1415 & & & 1434 & 1426,1416 & 1472 & $\delta\left(\mathrm{C}_{6}-\mathrm{H}\right), \delta\left(\mathrm{N}_{3}-\mathrm{H}\right)$ \\
\hline & 1390 & & 1383 & 1367 & 1390 & 1392 & $\delta\left(\mathrm{N}_{3}-\mathrm{H}\right), \delta\left(\mathrm{C}_{5}-\mathrm{H}\right)$ \\
\hline & & & 1366 & 1302 & & 1360 & $\nu\left(\mathrm{N}_{1} \mathrm{C}_{2}-\mathrm{C}_{2} \mathrm{~N}_{3}\right), \delta(\mathrm{ring})$ \\
\hline & 1230 & & 1250 & 1230 & 1237 & 1292 & $\delta\left(\mathrm{C}_{5}-\mathrm{H}\right), \nu\left(\mathrm{N}_{1} \mathrm{C}_{2}-\mathrm{C}_{2} \mathrm{~N}_{3}\right)$ \\
\hline & & & 1209 & 1136 & 1211 & 1181 & $\delta\left(\mathrm{C}_{6}-\mathrm{H}\right), \nu\left(\mathrm{C}_{2} \mathrm{~N}_{3}-\mathrm{N}_{3} \mathrm{C}_{4}\right)$ \\
\hline & 1093 & & 1095 & 1032 & 1099 & 1126 & $\nu\left(\mathrm{C}_{6}-\mathrm{N}_{1}\right), \delta\left(\mathrm{C}_{5}-\mathrm{H}\right)$ \\
\hline & 983 & & 1036 & & 985 & 1025,1009 & $\nu\left(\mathrm{N}_{1}-\mathrm{C}_{2}\right), \nu\left(\mathrm{N}_{3}-\mathrm{C}_{4}\right)$ \\
\hline & 825 & & & & 808 & 957 & $\omega_{\mathrm{wag}}\left(\mathrm{C}_{6}-\mathrm{H}, \mathrm{C}_{5}-\mathrm{H}\right)$ \\
\hline & 786 & & 796 & 794 & 780 & 792,716 & Ring breathing \\
\hline & 573 & & 613,585 & 604,573 & 563 & 594 & $\delta(\mathrm{R})$ \\
\hline & 551 & & 554 & 551 & 547 & 564 & $\delta(\mathrm{R})$ \\
\hline & 530 & & & & 526 & & $\delta(\mathrm{R})$ \\
\hline & 423 & & 438 & 433 & 405,385 & 427 & $\delta(\mathrm{R})$ \\
\hline & & & 221 & 221 & & 211 & $\nu(\mathrm{N}-\mathrm{Au})$ \\
\hline
\end{tabular}

${ }^{a}$ Calculated for adsorbed structure of $\mathrm{N}_{3} \mathrm{Au}_{1} \mathrm{~N}_{10} . . \mathrm{Au}_{2}$ for adenine, and $\mathrm{N}_{3} \mathrm{Au}_{1} \mathrm{~N}_{1} \mathrm{C}_{2}=\mathrm{O}$...Au $\mathrm{u}_{2}$ for uracil using a DFT method (see the main text in detail). Each Raman band was primarily assigned on the basis of free-standing molecules with the software VEDA, and former report [20-22]. 
nine molecule, supporting the above explanations. Experimentally observed Raman spectra at bulk powder state and SERS spectra on AuNPs were well reproduced at $1622,1510,1423,1367,1353,1328,1267,1238,1143$, $1097,1007,946,901,724,619,525$, and $279 \mathrm{~cm}^{-1}$ by DFT calculations (Fig. 5a, Table I) for a free-molecule with slight modifications in peak positions and intensity, indicating no drastic changes occurred in molecular structure upon adsorption on AuNPs. In contrast to a free-standing state of adenine, DFT calculation for adenine in flocculates of AuNPs is not so straightforward. This is because we have various molecular structures for DNA bases such as proton tautomers shown by keto-enol isomers, and also protonated and deprotonated state at primary amino ($\left.\mathrm{NH}_{2}\right)$ and imino $(>\mathrm{N}-\mathrm{H})$ groups. DNA bases with such different structures likely chemisorb on AuNPs via amino or imino groups in A, C, G, T and U, and carbonyl groups in $\mathrm{C}, \mathrm{T}$ and $\mathrm{U}$, while base molecules also physisorb on AuNPs. DFT calculations for DNA bases in flocculates of AuNPs should cover a large number of configurations for all these structures, in which bases adsorb on AuNPs via at least two sites. Furthermore, if we take into account hydration using explicit molecular structures of water [24], instead of using a continuous media model, or metal clusters like $\mathrm{Ag}_{3}$ [25] or $\mathrm{Au}_{4}$ [26] to get insight into electronic state of metals and adsorbates, vast amount of computing resources are prerequisite. These considerations are beyond our present scope that deduces plausible adsorbed structures of DNA and RNA bases on AuNPs. Here, we perform DFT calculations for a limited number of plausible adsorbed structures for DNA and RNA bases on AuNPs to reproduce the observed SERS spectra, while using isotope shift of SERS spectra by deuteration of amino or imino groups in base molecules.

For the first adsorption site in adenine, we adopted three distinct structures coordinating on an $\mathrm{Au}$ atom via lone pair electrons at $\mathrm{N}_{1}, \mathrm{~N}_{3}$ and $\mathrm{N}_{7}$ amino groups (Fig. 1a). Among these structures, adenine adsorbed on an $\mathrm{Au}$ atom via $\mathrm{N}_{3}$ provided Raman spectra most similar to those observed (Data not shown). Other sites yielded significantly different spectra, such as adsorption at an $\mathrm{N}_{1}$ site gave larger intensity for Raman bands at higher wavenumber region, and that at $\mathrm{N}_{7}$ site yielded remarkably strong out-of-plane bending mode, $\gamma_{\mathrm{C}-\mathrm{H}}$, at $\sim 800 \mathrm{~cm}^{-1}$ (Data not shown). To get insight into the second adsorption site, isotope shift of SERS spectra was examined for adenine on AuNPs. We experimentally observed that deuteration of amino groups in adenine gave pronounced shift in scissoring mode of $-\mathrm{NH}_{2}$ at $1600 \mathrm{~cm}^{-1}$ to 1186 and $1099 \mathrm{~cm}^{-1}$ and a rocking mode of $-\mathrm{NH}_{2}$ from 1233 to $851 \mathrm{~cm}^{-1}$, as well as that in bending mode for $\mathrm{N}_{9}-\mathrm{H}$ from 1394 to $1262 \mathrm{~cm}^{-1}$ [20]. These spectral changes by deuteration indicate that an $\mathrm{N}-\mathrm{H}$ bond in adenine remains even after adsorption on AuNPs. By taking this observation into account, $\mathrm{N}_{10}$ (in $-\mathrm{NH}_{2}$ at $\mathrm{C}_{6}$ ) atom which weakly interacts with $\mathrm{Au}$ surfaces, abbreviated as $\mathrm{N}_{3} \mathrm{Au}_{1} \mathrm{~N}_{10} . . \mathrm{Au}_{2}$ structure, is examined for the second adsorption site. Thus, DFT calculations were performed for adenine adsorbed on AuNPs via an $\mathrm{N}_{3}$ $\mathrm{Au}$ coordination bond (first site) and via $-\mathrm{N}_{10} \mathrm{H}_{2}$ (second site), abbreviated as $\mathrm{N}_{3} \mathrm{Au}_{1} \mathrm{~N}_{10} . . \mathrm{Au}_{2}$ structure (Fig. 5), which provided SERS spectra at 1641, 1614, 1486, 1473, 1403, 1386, 1317, 1270, 1230, 1168, 1118, 1006, 947,
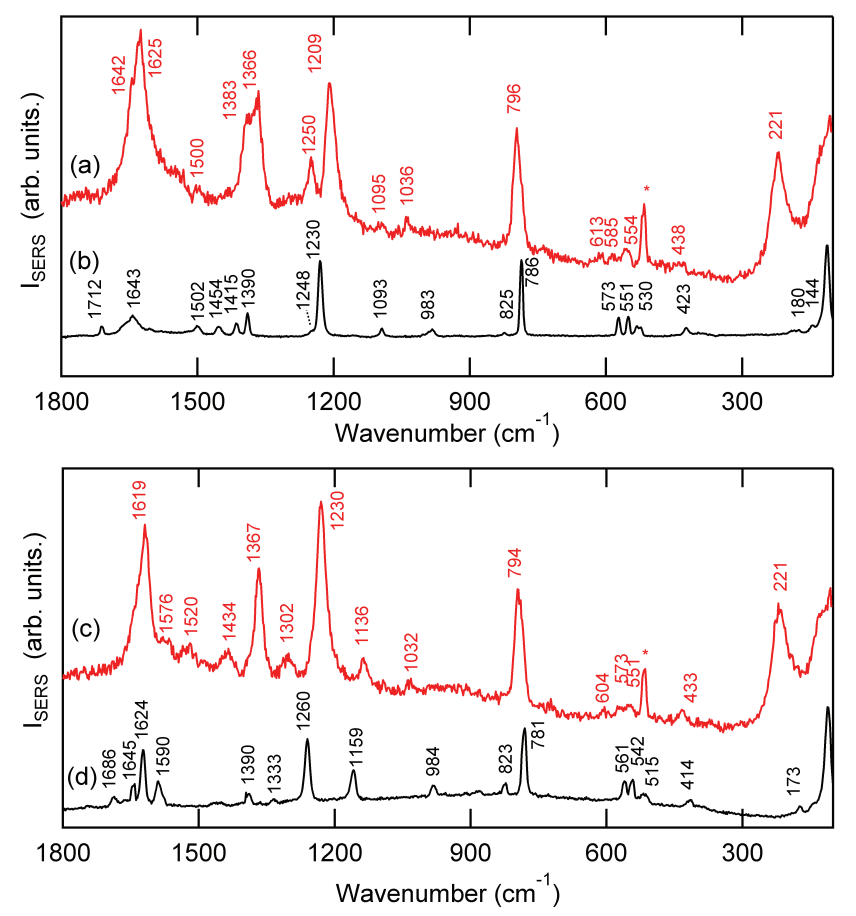

FIG. 6. Raman spectra of uracil $(>\mathrm{NH}$, (a) and $>\mathrm{N}-\mathrm{D}$ (c)) adsorbed on AuNPs as well as bulk powder (b, and d).

$746,689,635,619,555,463,303$ and $200 \mathrm{~cm}^{-1}$ inherently similar to those experimentally observed (Fig. 5b and Table I). We have also examined other structures for a proton tautomer of adenine having $>\mathrm{N}_{3}-\mathrm{H}$ and $>\mathrm{N}_{9}$ groups, which adsorbs on AuNP via $\mathrm{N}_{9}-\mathrm{Au}$ coordination and weaker interaction with $>\mathrm{N}_{1}$ and $-\mathrm{N}_{10} \mathrm{H}_{2}$ groups, abbreviated as $\mathrm{N}_{9} \mathrm{Au}_{1} \mathrm{~N}_{10} . . \mathrm{Au}_{2}$ structure. Namely, this second structure is inherently equivalent to the first one $\mathrm{N}_{3} \mathrm{Au}_{1} \mathrm{~N}_{10} . . \mathrm{Au}_{2}$. The adsorbed structure of $\mathrm{A}$ via $\mathrm{N}_{9}$ lone pair to $\mathrm{Au}$ surfaces gave slightly negative wavenumber for an out-of-plane deformation mode $\gamma_{\mathrm{Au}-\text { Adenine, }}$ indicating slightly less stable than $\mathrm{N}_{3} \mathrm{Au}_{1} \mathrm{~N}_{10} . . \mathrm{Au}_{2}$ structure. Adsorbed structure $\mathrm{N}_{9} \mathrm{Au}_{1} \mathrm{~N}_{10} . . \mathrm{Au}_{2}$ structure gave SERS spectra similar to $\mathrm{N}_{3} \mathrm{Au}_{1} \mathrm{~N}_{10}$.. $\mathrm{Au}_{2}$ structure (data not shown). Such structures like $\mathrm{N}_{3} \mathrm{Au}_{1} \mathrm{~N}_{10} . . \mathrm{Au}_{2}$ and $\mathrm{N}_{9} \mathrm{Au}_{1} \mathrm{~N}_{10} . . \mathrm{Au}_{2}$ are compatible with the observation of only slight decrease in ccf values at neutral $\mathrm{pH}$ compared to acidic conditions, as deprotonation of an $>\mathrm{N}-\mathrm{H}$ group in adenine is not necessary. Consequently, these DFT calculations indicate that such adsorbed structures of adenine on AuNPs, are most plausible, having one coordination bond of $\mathrm{N}-\mathrm{Au}$, and weak interaction with other amino groups, while retaining an $>\mathrm{N}-\mathrm{H}$ bond.

\section{Adsorbed state of uracil molecules on AuNPs}

Next, we investigated adsorbed state of uracil, exemplifying base molecules without an $-\mathrm{NH}_{2}$ group, on AuNPs. Uracil molecules showed much higher ccf values compared with $\mathrm{A}, \mathrm{G}$, and $\mathrm{C}$ with an $-\mathrm{NH}_{2}$ group, which are much lower by a factor of $1 / 30$ at neutral $\mathrm{pH}(=6.8)$ than those at acidic $\mathrm{pH}(=4.3)$. These observations are not due to deprotonation of $\mathrm{U}$ as $\mathrm{pK}_{a} \sim 9$, but probably caused by 

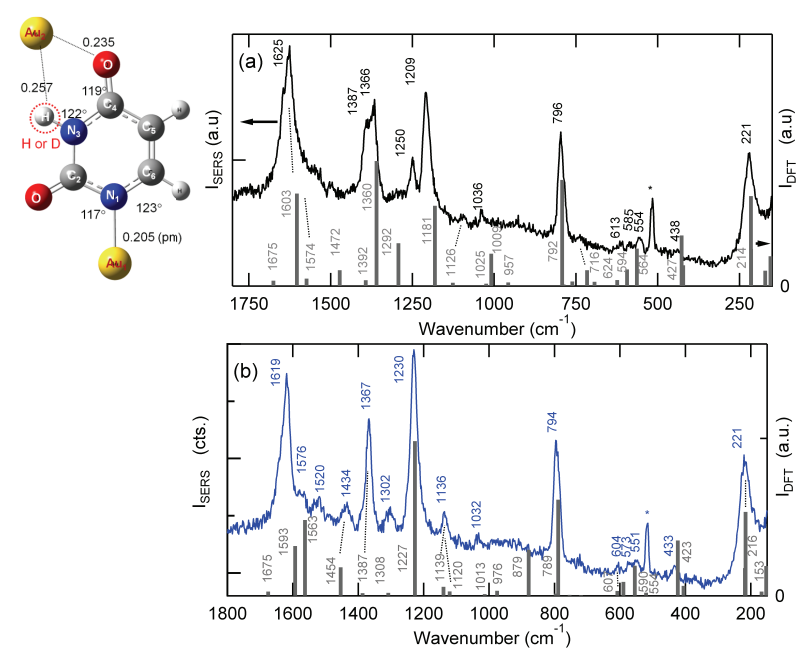

FIG. 7. Calculated Raman spectra of uracil adsorbed on AuNPs: (a) with $>\mathrm{N}-\mathrm{H}$ groups, and (b) with $>\mathrm{N}-\mathrm{D}$ groups, in which uracil chemisorbs on $\mathrm{Au}$ surfaces via $\mathrm{N}_{1}-\mathrm{Au}_{1}$, and simultaneously physisorbs via $\mathrm{N}_{3}-\mathrm{H}$ and $\mathrm{C}_{4}=\mathrm{O}$ (see text in detail). Experimentally observed spectra are also shown at upper side of each figure. Plausible optimized structure of U adsorbed on Au using DFT calculation is also shown, which is stabilized by a coordination bond of $\mathrm{N}_{1}-\mathrm{Au}_{1}$, and weak interaction between $\mathrm{N}_{3}, \mathrm{C}_{4}=\mathrm{O}$ and $\mathrm{Au}_{2}$ atoms.

adsorbed structure of U on Au surfaces. SERS spectra of $\mathrm{U}$ in flocculates of AuNPs observed in neutral pH (7.3) at 1642, 1625, 1500, 1383, 1366, 1250, 1209, 1095, 1036, 796, $613,585,554,438$, and $221 \mathrm{~cm}^{-1}$ are corresponded well with those for bulk powder sample at 1712, 1643, 1502, 1454, 1415, 1390, 1248, 1230, 1093, 983, 825, 786, 573, $551,530,423 \mathrm{~cm}^{-1}$ (Figs. 6a and 6b, Table I). Interestingly, SERS spectra of U on AuNPs showed a $\nu_{\mathrm{Au}-\mathrm{N}}$ band at $221 \mathrm{~cm}^{-1}$, a definite evidence for deprotonation of an $>\mathrm{N}-\mathrm{H}$ group followed by the formation of $\mathrm{Au}-\mathrm{N}$. To get further insight into adsorbed state of $\mathrm{U}$ on $\mathrm{Au}$, we used deuteration of amino groups in $\mathrm{U}$ molecules as well as for adenine. Interestingly, significant SERS spectral changes in $1600-1100 \mathrm{~cm}^{-1}$ region were observed for the deuteration of imino groups $(>\mathrm{N}-\mathrm{H})$ in $\mathrm{U}$ molecule adsorbed on AuNPs. For instance, Raman bands at 1642, 1625, 1383, 1366, 1250, 1209, 1095, and $1036 \mathrm{~cm}^{-1}$ for U with $-\mathrm{NH}$ groups were modified to those at 1619, 1576, 1520, 1434, $1367,1302,1230,1136$, and $1032 \mathrm{~cm}^{-1}$ for U with -ND groups (Figs. 6a and 6c). Such spectral changes definitely identify that at least one of $>\mathrm{N}-\mathrm{H}$ bonds is retained after deuteration of U molecules adsorbed on AuNPs. Indeed, a $\delta_{\mathrm{N}-\mathrm{H}}$ bending mode blue-shifted from $1210 \mathrm{~cm}^{-1}(>\mathrm{N}-\mathrm{H})$ to $1230 \mathrm{~cm}^{-1}(>\mathrm{N}-\mathrm{D})$. Similar peak shift was observed for bulk powder sample of $\mathrm{U}$ molecules from $1230 \mathrm{~cm}^{-1}(>\mathrm{N}-$ $\mathrm{H})$ to $1260 \mathrm{~cm}^{-1}(>\mathrm{N}-\mathrm{D})$ (Figs. $6 \mathrm{~b}$ and $\left.6 \mathrm{~d}\right)$. These experimental observations suggest plausible adsorbed structures of $\mathrm{U}$ molecules on AuNPs as presented in the following section.

In DFT calculations, keto forms that are thermally more stable than enol forms gave Raman spectra for freestanding U molecules, which are consistent with those experimentally observed for bulk powder samples (Figs. 6 and $7 \mathrm{a}$ ). Keto structures have various adsorption sites in a pyrimidine ring such as two imino groups $(>\mathrm{N}-\mathrm{H})$ at $\mathrm{N}_{1}$ and $\mathrm{N}_{3}$, and two carbonyl groups $(>\mathrm{C}=\mathrm{O})$ at $\mathrm{C}_{2}$ and $\mathrm{C}_{4}$. One of $\mathrm{N}-\mathrm{H}$ bonds in $\mathrm{U}$ should be deprotonated to form coordination bonds with $\mathrm{Au}$ surfaces. We adopted a plausible candidate for adsorption structure of $U$, in which a lone pair electrons at $\mathrm{N}_{1}$ coordinate to an $\mathrm{Au}$ atom, while $\mathrm{N}_{3}$ and $\mathrm{C}_{4}=\mathrm{O}$ bond weakly interact with another $\mathrm{Au}$ atom, abbreviated as $\mathrm{N}_{1} \mathrm{Au}_{1} \mathrm{~N}_{3} \mathrm{C}_{4}=\mathrm{O}$... $\mathrm{Au}_{2}$ (Fig. 7), on the basis of experimental observations. This adsorption structure provided theoretical SERS spectra at $1675,1603,1574,1472,1360,1181,1126,1025,1009$, $792,716,624,594,564,427$ and $214 \mathrm{~cm}^{-1}$ corresponded well with those observed (Figs. 6a and 7a). DFT calculation for the adsorbed structure $\mathrm{N}_{1} \mathrm{Au}_{1} \mathrm{~N}_{3} \mathrm{C}_{4}=\mathrm{O}$... $\mathrm{Au}_{2}$ of $\mathrm{U}$ on AuNPs gave spectral changes by deuteration of $>\mathrm{NH}$ groups, such as blue shift of $\delta_{\mathrm{N}-\mathrm{H}}$ mode from $1181 \mathrm{~cm}^{-1}$ to $1227 \mathrm{~cm}^{-1}$, corresponding to the observed peak at 1209 and $1230 \mathrm{~cm}^{-1}$ (Figs. 7a and 7b). Another adsorbed structures such as those with two coordination bonds $(>\mathrm{N}-\mathrm{Au})$ by deprotonation of both $>\mathrm{N}-\mathrm{H}$ groups, which are obviously inconsistent with experimental observation in SERS for deuterated U molecules (vide supra), did not have stable structures.

\section{CONCLUSION}

We have succeeded in forming flocculates of gold nanoparticles (AuNPs) using DNA and RNA bases to obtain their surface enhanced Raman spectra. Adenine, guanine and cytosine molecules which possess a primary amino group $\left(-\mathrm{NH}_{2}\right)$ formed flocculates at much lower concentration than uracil and thymine without an $-\mathrm{NH}_{2}$ group, which is inherently related to their adsorbed structures. We found that similar adsorbed structure for these distinct base molecules such as A and U bases, which is described by one coordination bond through a lone pair electrons at an $>\mathrm{N}$ group, and the other weak adsorption nearby another $>\mathrm{N},>\mathrm{C}=\mathrm{O}$ and $-\mathrm{NH}_{2}$ groups. Such adsorption is facilitated by the existence of an $-\mathrm{NH}_{2}$ group in $\mathrm{A}, \mathrm{G}$ and $\mathrm{C}$ by stronger van der Waals interaction, whereas inhibited in acidic conditions due to prerequisite deprotonation for $\mathrm{T}$ and $\mathrm{U}$ molecules.

\section{ACKNOWLEDGMENTS}

This research was supported by KAKENHI (21310071 and also 23651102) in JSPS, and by Salt Science Research Foundation (Grant No. 1415 in 2014). Also, M.F. thanks Prof. Mitsuru Ishikawa (Josai University) for useful discussion.
[1] K. Kneipp, M. Moskovic, and H. Kneipp, Eds., Surface Enhanced Raman Scattering (Springer, Berlin, 2006).
[2] E. C. Le Ru and P. G. Etchegoin, Principles of SurfaceEnhanced Raman Spectroscopy (Elsevier, 2009). 
[3] M. Futamata, T. Yanatori, T. Kokubun, and Y. Yu, J. Phys. Chem. C 114, 7502 (2010).

[4] M. Futamata, Y. Yu, and T. Yajima, J. Phys. Chem. C 115, 5271 (2011).

[5] Y. Yu, S. Handa, T. Yajima, and M. Futamata, Chem. Phys. Lett. 560, 49 (2013).

[6] T. Yajima, Y. Yu, and M. Futamata, Phys. Chem. Chem. Phys. 13, 12454 (2011).

[7] T. Yajima, Y. Yu, and M. Futamata, J. Raman Spectrosc. 44, 406 (2013).

[8] P. K. Aravind and H. Metiu, Surf. Sci. 124, 506 (1984).

[9] K. Ikeda, K. Takahashi, T. Masuda, H. Kobori, M. Kanehara, T. Teranishi, and K. Uosaki, J. Phys. Chem. C 116, 20806 (2012).

[10] K. Kim, H. B. Lee, J-Y. Choi, and K. S. Shin, J. Phys. Chem. C 115, 21047 (2012).

[11] H. Suzuki, H. Chiba, and M. Futamata, Vibrational Spectrosc. 72, 105 (2014).

[12] M. Futamata, M. Ishikura, S. Handa, and C. Iida, Faraday Discussions 178, in press (DOI: 10.1039/c4fd00188e).

[13] T. Yano, T. Ichimura, S. Kuwahara, F. H'Dhili, K. Uetsuki, Y. Okuno, P. Verma, and S. Kawata, Nat. Commun. 4, 2592 (2013).

[14] Z. Liu, S-Y. Ding, Z-B. Chen, X. Wang, J-H. Tian, J. R. Anema, X-S. Zhou, D-Y. Wu, B-W Mao, X. Xu, Bin Ren, and Z-Q. Tian, Nat. Commun. 2, 305 (2011).
[15] J. N. Israelachvili, Intermolecular and Surface Forces (Academic Press, London, 1991).

[16] S. Handa, Y. Yu, and M. Futamata, Vibrational Spectrosc. 72, 128 (2014).

[17] For example, N. E. Marotta, K. R. Beavers, and L. A. Bottomley, Anal. Chem. 85, 1440 (2013), and A. Barhoumi, and N. J. Halas, J. Am. Chem. Soc. 132, 17292 (2010).

[18] L. D. Menard, C. E. Mair, M. E. Woodson, J. P. Alarie, and J. Michaely, ACS Nano 6, 9087 (2012).

[19] S. Bell, Proc. ICORS 2014, WeP-O-007.

[20] B. Giese and D. McNaughton, J. Phys. Chem. B 106, 1461 (2002), and ibid. 106, 101 (2002).

[21] R. Aroca and R. Bujalski, Vibrational Spectrosc. 19, 11 (1999).

[22] E. Papadopoulou and S. E. Bell, J. Phys. Chem. C 114, 22644 (2010).

[23] G. Frens, Nature Phys. Sci. 241, 20 (1973).

[24] R. Huang, L-B. Zhao, D-Y. Wu, and Z-Q. Tian, J. Phys. Chem. C 115, 13739 (2011).

[25] R. Huang, H-T. Yang, L. Cui, D-Y. Wu, B. Ren, and Z-Q. Tian, J. Phys. Chem. C 117, 23730 (2013).

[26] E. S. Kryachiko and R. Remacle, Nano Lett. 5, 735 (2005).

[27] M. Östblom, B. Liedberg, L. M. Demers, and C. A. Mirkin, J. Phys. Chem. B 109, 15150 (2009).

[28] M. H. Jamroz, Spectrochimica Acta A 114, 220 (2013).

[29] V. Verdolino, R. Cammi, B. H. Munk, and H. B. Schlegel, J. Phys. Chem. B 112, 16860 (2008) and references therein. 